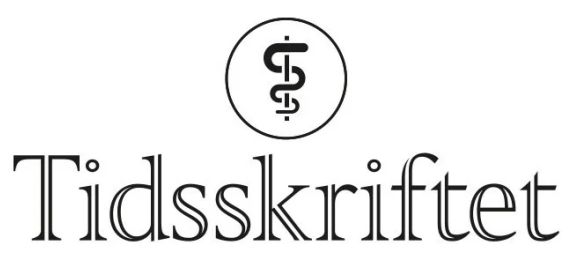

DEN NORSKE LEGEFORENING

\title{
Ny utgave av lærebok i rettsmedisin
}

\author{
ANMELDELSER
}

LARS UHLIN-HANSEN

Professor i rettsmedisin og patologi

UiT - Norges arktiske universitet

Jørgen Lange Thomsen, red.

Retsmedicin

4. utg. 448 s, tab, ill. København: FADL's Forlag, 2021. Pris DKK 500

ISBN 978-87-93590-52-6

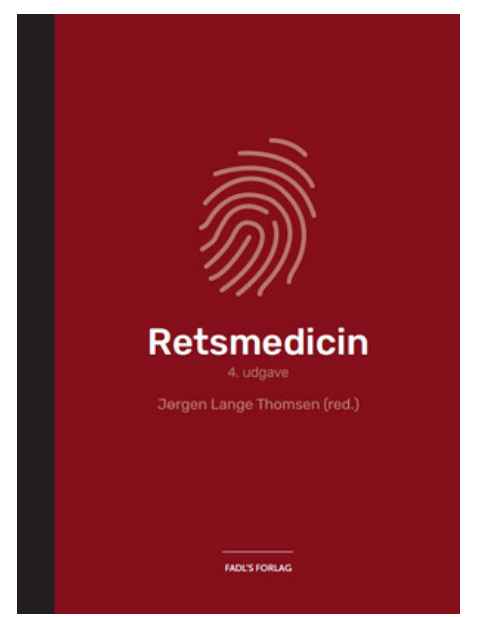

I forordet er det angitt at boken dekker pensum i rettsmedisin for legestudiet ved de danske universiteter. I den nye utgaven er enkelte emner tatt ut fordi de undervises i andre fag, mens to nye emner er kommet med: gjerningsmannsprofiler og rettsmedisinsk forskning.

I motsetning til den første utgaven fra 2004 som hadde medforfattere fra alle nordiske land, har denne utgaven danske forfattere samt noen få norske. Man har da også valgt å fjerne «nordisk» fra tittelen. Som tidligere er språket dansk.

Boken er oppbygd som en tradisjonell lærebok, og med sine 41 kapitler dekkes til sammen de fleste rettsmedisinske emner. Den er rikt illustrert, men dessverre er de fleste bildene så små at de har liten pedagogisk verdi. 
Forfatterne sier i forordet at de med den nye utgaven har forsøkt å forbedre relevansen for legestudentene. Dette har de ikke lyktes med. Selv om boken gir en god oversikt over forskjellige rettsmedisinske temaer, gir den kun i liten grad svar på de rettsmedisinske problemstillingene som «vanlige» leger står overfor i sitt daglige virke. For de ytterst få legene som velger en rettsmedisinsk karrierevei, kan boken fungere som en introduksjon til fagfeltet. Det samme gjelder for jurister, journalister og andre som er ute etter økt kunnskap om rettsmedisinske temaer. De fleste vil da kanskje foretrekke den norske læreboken som er mer relevant for norske forhold: Lcerebok $i$ rettsmedisin redigert av Torleiv Ole Rognum. For øvrig er den danske og den norske læreboken stort sett lik både i innhold og i antall sider.

Publisert: 27. september 2021. Tidsskr Nor Legeforen. DOI: 10.4045/tidsskr.21.0488

(C) Tidsskrift for Den norske legeforening 2023. Lastet ned fra tidsskriftet.no 26. april 2023. 